Published in final edited form as:

Injury. 2008 April ; 39(Suppl 1): S97-113. doi:10.1016/j.injury.2008.01.034.

\title{
Concepts in Gene Therapy for Cartilage Repair
}

\author{
Andre F. Steinert ${ }^{1}$, Ulrich Nöth ${ }^{1}$, and Rocky S. Tuan ${ }^{2}$ \\ ${ }^{1}$ Orthopaedic Center for Musculoskeletal Research König-Ludwig-Haus, Julius-Maximilians- \\ University, Würzburg, Germany \\ ${ }^{2}$ Cartilage Biology and Orthopaedics Branch National Institute of Arthritis, and Musculoskeletal and \\ Skin Diseases National Institutes of Health, Department of Health and Human Services Bethesda, \\ MD, U.S.A.
}

\section{Summary}

Once articular cartilage is injured, it has a very limited capacity for self-repair. Although current surgical therapeutic procedures to cartilage repair are clinically useful, they cannot restore a normal articular surface. Current research offers a growing number of bioactive reagents, including proteins and nucleic acids, that may be used to augment different aspects of the repair process. As these agents are difficult to administer effectively, gene transfer approaches are being developed to provide their sustained synthesis at sites of repair.

To augment regeneration of articular cartilage, therapeutic genes can be delivered to the synovium, or directly to the cartilage lesion. Gene delivery to the cells of the synovial lining is generally considered more suitable for chondroprotective approaches, based on the expression of antiinflammatory mediators. Gene transfer targeted to cartilage defects can be achieved by either direct vector administration to cells located at or surrounding the defects, or by transplantation of genetically modified chondrogenic cells into the defect. Several studies have shown that exogenous cDNAs encoding growth factors can be delivered locally to sites of cartilage damage, where they are expressed at therapeutically relevant levels. Furthermore, data is beginning to emerge indicating, that efficient delivery and expression of these genes is capable of influencing a repair response toward the synthesis of a more hyaline cartilage repair tissue in vivo. This review presents the current status of gene therapy for cartilage healing and highlights some of the remaining challenges.

\section{Keywords}

articular cartilage; gene therapy; chondrocyte; mesenchymal stem cell; growth factor

\section{Introduction}

The application of gene transfer to articular tissues was pioneered by Evans and co-workers, as a means to treat arthritis [46,49]. Initial encouraging experiments in animal models using retroviral-mediated gene delivery formed the basis for a clinical trial to evaluate the safety and feasibility of using gene therapy for rheumatoid arthritis $[46,49,59-61,148]$. The study was completed without incident; the procedure was well-tolerated by the nine participants, and intra-articular gene transfer and expression was observed in all joints treated [46,49]. The relative success of these studies suggests that this technology may have application in treating a number of articular disorders for which current treatment modalities are unsatisfactory.

Corresponding author Dr. Rocky S. Tuan, Branch Chief, Cartilage Biology and Orthopaedics Branch, National Institute of Arthritis, and Musculoskeletal and Skin Diseases, National Institutes of Health, Building 50, Room 1523, 50 South Drive MSC 8022, Bethesda, MD, 20892-8022, USA, Phone: +001 301-451-6854, Fax: +001 301-435-8017, E-mail: E-mail: tuanr@mail.nih.gov. 
Compared to the treatment of chronic or genetic diseases, where likely a lifelong expression of a corrective transgene is required, the use of gene transfer techniques to facilitate musculoskeletal tissue repair offers perhaps an immediate opportunity for a clinical application of gene therapy, as it may only require transient, localized expression of a specific transgene product. Whereas good success has been achieved by gene transfer to bone healing [9], augmenting the repair of focal articular cartilage defects by gene transfer has not been straightforward. Current research indicates that the design of a successful genetic approach for cartilage repair includes a refined strategy of gene delivery that meets the complexities of treating this tissue. This review aims to summarize some of the basic principles of cartilage injury and regeneration, and comments on the pros and cons of recent gene therapy approaches to repair, as well as future challenges.

\section{Cartilage injury and limitations of current treatments}

Hyaline articular cartilage is a highly specialized tissue that protects the bones of diarthrodial joints from forces associated with load bearing, friction and impact. Although a remarkably durable tissue, once articular cartilage is injured, it has very limited capacities for self-repair. In partial thickness defects, where a lesion is wholly contained within the articular cartilage, there is no involvement of the vasculature. Consequently, chondroprogenitor cells in blood and marrow cannot enter the damaged region to influence or contribute to the reparative process. Resident articular chondrocytes do not migrate to the lesion, and production of a reparative matrix by these cells does not occur. As such, the defect is not filled or repaired and essentially remains permanently $[21,80]$. Full thickness cartilage injuries result in damage to the chondral layer and subchondral bone plate, causing rupture of blood vessels, and hematoma formation at the injury site. In this case, a repair response is initiated that results in the formation of a fibrocartilage repair tissue within weeks $[21,80]$.

In focal cartilage defects, where a stable fibrocartilaginous repair tissue has not formed, and patients are suffering clinical symptoms such as pain and swelling, surgeons aim to promote a natural fibrocartilaginous response, by using marrow stimulating techniques, such as abrasion arthroplasty, Pridie drilling, or microfracture. These procedures are cost effective and clinically useful, as patients often have reduced pain and improved joint function, and are therefore generally considered as first-line treatment for focal cartilage defects $[22,121,122,161,162]$. However, fibrocartilage has inferior mechanical and biochemical characteristics compared to normal hyaline articular cartilage. It is poorly organized, contains significant amounts of collagen type I, and is susceptible to injury. The inferior repair matrix breaks down with time and loading, which ultimately leads to premature OA $[21,80]$. Therefore, as outlined in other articles of this issue, the aim of modern therapeutic techniques is to achieve a more hyalinelike cartilage repair tissue by transplanting tissues or cells. Tissue transplantation procedures such as periosteum, perichondrium, or osteochondral grafts have shown positive short term results for a number of patients, but the long term clinical results are uncertain, with tissue availability for transplant being a major limitation, especially in large cartilage defects [19, $22,23,71,80]$. Therefore, the autologous chondrocyte transplantation (ACT) procedure has been used clinically since 1987 in combination with a periosteal cover to treat chondral or osteochondral defects of the knee with good clinical results [20,121,144,145]. Modern modifications of this procedure include embedding chondrocytes in a three dimensional matrix before transplantation into cartilage defects $[15,114,123]$. Despite these advances, most surgical interventions only result in improvement of clinical symptoms, such as pain relief, but none of the current treatment options has regenerated long-lasting hyaline cartilage repair tissue yet $[22,80,121,144]$. Therefore, tissue engineering approaches are being aggressively investigated in an effort to engineer cartilage in vitro to produce grafts to facilitate regeneration of articular cartilage in vivo. In most cases, cells are harvested by enzymatic digestion or outgrowth culture, which are thereafter extensively expanded in culture. The cells are then 
seeded onto various biologically compatible scaffolds, and cultured in the presence of a specific cytokine or growth factor, or a cocktail of bioactive factors. However, despite promising in vitro data with several approaches, a significant improvement compared to current cartilage repair modalities, has yet to be achieved. Many challenges thus remain for successful cellbased cartilage repair approaches to form hyaline repair tissue in vivo $[23,80,92,177]$. Impairments of hyaline neo-cartilage formation is likely due to a number of reasons, including insufficient differentiation, loss of transplanted cells or tissues, matrix destruction and integration failures, which all can occur due to various reasons.

\section{Candidate gene products}

In recent years, several factors have been identified that might be functional in augmenting different aspects of cartilage tissue repair. Of particular interest are morphogens and transcription factors that promote differentiation along chondrogenic lineages, growth factors that promote matrix synthesis, inhibitors of osteogenic or hypertrophic differentiation, antagonists that inhibit apoptosis, senescence or responses to catabolic cytokines (Table 1). Several of these substances have shown promise in animal models of cartilage repair and regeneration, but their clinical application is hindered by delivery problems $[103,164,171]$. Due to the limited half-lives of many proteins in vivo, they are particularly difficult to administer to sites of cartilage damage at therapeutic concentrations and for sustained periods of time. Localized delivery of these agents without involvement of non-target organs has also proven to be problematic $[164,171]$. We suggest that these limitations may be overcome by adapting appropriate gene transfer technologies. In particular, it should be possible to develop techniques for transferring therapeutic genes encoding the necessary gene products to cells at the sites of injury or disease, for sustained local expression at high levels with minimal collateral exposure of non-target tissues [164,171]. In this manner, the proteins of interest are synthesized locally by cells and are presented to the microenvironment in a natural fashion. Furthermore, recombinant proteins produced by overexpression in bacteria may have altered activity, since they may not be similarly modified post-translationally as when synthesized by a mammalian cell [113].

The list of potentially useful cDNAs for cartilage repair (Table 1) comprises members of the transforming growth factor (TGF)- $\beta$ superfamily, including TGF- $\beta$ s 1,2 , and 3 , several of the bone morphogenetic proteins (BMPs), insulin-like growth factor (IGF)-1, fibroblast growth factors (FGFs), and epidermal growth factor (EGF), among others (reviewed in [74,103]). Other secreted proteins, such as indian hedgehog (IHH) or sonic hedgehog (SHH), play key roles in regulating chondrocyte hypertrophy [185], and may also prove to be beneficial for modulating the chondrocytic phenotype of grafted cells. Another class of biologics that may be useful in cartilage repair is transcription factors that promote chondrogenesis or the maintenance of the chondrocyte phenotype. SOX9 and related transcription factors like LSOX5, and SOX6 have been identified as essential for chondrocyte differentiation and cartilage formation [98]. Signal transduction molecules, such as SMADs, are also known to be important regulators of chondrogenesis [76]. As these molecules function completely intracellularly, they cannot be delivered in soluble form, and gene transfer might be the only way to harness these factors for repair. Alternatively, delivery and expression of cDNAs encoding specific extracellular matrix (ECM) components such as collagen type II, tenascin, or cartilage oligomeric matrix protein (COMP), may also be used to support production and maintenance of the proper hyaline cartilage matrix [37].

Prevention or treatment of cartilage loss may also require the inhibition of the actions of certain pro-inflammatory cytokines, such as interleukin (IL)- 1 and tumor necrosis factor (TNF)- $\alpha$, as these are important mediators of cartilage matrix degradation and apoptosis after trauma and disease. Therefore, anti-inflammatory or immunmodulatory mediators, such as interleukin-1 
receptor antagonist (IL-1Ra), soluble receptors for TNF (sTNFR) or IL-1 (sIL-1R), IL-4 or IL-10, inhibitors of matrix metalloproteinases, and others may be administered to effectively reduce loss of repair cells and matrix [148].

Inhibitors of apoptosis or senescence, such as Bcl-2, Bcl-XL, hTERT, i(NOS) and others (Table 1), may also be beneficially employed in order to maintain cell populations at the injury site, which are capable of favorable repair responses [39,41]. Different candidate cDNAs might also be administered in combination, especially when favoring complementary therapeutic responses. For example, the combined administration of an anabolic growth factor (e.g. IGF-1) together with an inhibitor of the catabolic action of inflammatory cytokines (e.g. IL-1Ra) has the potential to control matrix degradation as well as to allow partial restoration of the damaged cartilage matrix $[73,132]$.

\section{Strategies to gene therapy in the repair of articular cartilage}

There are many strategies that can be used to deliver exogenous cDNAs for the treatment of diseased or damaged cartilage. For a successful approach, several factors have to be taken into account, including the extent of cartilage pathology, disease processes, and the biological activity of the gene product, among others. A key component for any gene therapy application is a vector that efficiently delivers the cDNA of interest to the target cell, and enables transgene expression of a suitable level and duration to affect the desired biological response.

Furthermore, an understanding of the natural behavior of the target cell, such as its half-life, rate of division, and infectability with the vector are also essential to the effectiveness of the procedure. The properties of commonly used vectors in gene therapy applications are summarized in Table 2, and have been extensively reviewed elsewhere [136,168]. Genetransfer strategies in which these vectors are currently used for cartilage repair, range from those as simple as direct delivery of a vector to a defect, to synthesis of cartilaginous constructs through genetically augmented tissue engineering procedures. We will present below an overview on the properties of commonly used vectors in gene therapy applications (Table 2), and will discuss their use in the context of the different delivery strategies to cartilage defects.

There are two general modes of intra-articular gene delivery, a direct in vivo, and an indirect ex vivo approach (Figure 1). The direct in vivo approach involves the application of the vector directly into the joint space, whereas the ex vivo approach involves the genetic modification of cells outside the body, followed by re-transplantation of the modified cells into the body. The choice of which gene transfer method to use is based upon a number of considerations, including the gene to be delivered, and the vector used. In general, adenovirus, herpes simplex virus, adeno-associated virus vectors, lentivirus and non-viral vectors may be used for in vivo and ex vivo delivery (Figure 1, Table 2). Retroviral vectors, because of their inability to infect non-dividing cells, are more suited for ex vivo use. Ex vivo approaches are generally more invasive, expensive and technically tedious. However, they permit control of the transduced cells and safety testing prior to transplantation. In vivo approaches are simpler, cheaper, and less invasive, but viruses are introduced directly into the body, which limits safety testing.

Toward the treatment of damaged articular cartilage, the three primary candidate cell types to target genetic modification are synovial lining cells, chondrocytes, and mesenchymal stem cells.

\section{Gene delivery to the synovium}

The simplest strategy for gene delivery to diseased joints is by direct intra-articular injection of a recombinant vector $[60,61]$. For this application, the two primary tissues to consider are cartilage and synovium. Within articular cartilage, chondrocytes are present at low density and 
reside at varying depths within the dense matrix. Because of this, efficient genetic modification of chondrocytes in situ has not been effectively achievable $[32,62,170,192]$. The synovium, in contrast, is a tissue that is much more amenable to gene delivery. It usually exists as a thin lining of cells that covers all internal surfaces of the joint except that of cartilage, and thus has a relatively large surface area, and is therefore the predominant site of vector interaction. Direct intra-articular injection of vector or modified cells results in synthesis and release of therapeutic proteins into the joint space, which then bathe all available tissues, including cartilage. Using various types of vectors in ex vivo and in vivo approaches, considerable progress has been made towards defining the parameters critical to effective gene transfer to synovium and prolonged intra-articular expression. The effectiveness of synovial gene transfer of various transgenes is well documented in research directed towards rheumatoid arthritis [148]. Ex vivo gene delivery to joints has since been taken into phase I clinical trial and shown to be feasible and safe in humans with RA [46,50].

Although most of the work involving direct intra-articular gene delivery has been focused toward the study and treatment of RA, data are beginning to emerge of its potential for treating OA (reviewed in [47]), and to augment repair approaches of focal cartilage defects (Table 3) $[31,58,164,171]$. For example, encouraging results have been reported for adenovirally delivered IGF-1 or IL-1Ra using animal models for OA and localized cartilage injury [32, 54]. While it is possible to achieve biologically relevant levels of transgene expression by both direct and ex vivo gene transfer to synovium, this approach is not compatible with the delivery of certain growth factors. For example, adenoviral mediated delivery of TGF- $\beta 1$ or BMP- 2 to the synovial lining was found to generate joint fibrosis, extreme swelling, osteophytes and cartilage degeneration $[8,56,57,120]$. Considering these results in the context of cartilage repair, synovial gene transfer may be more suitable for delivering chondroprotective agents rather than strong anabolic transgenes with pleiotropic effects of their products. Many antiinflammatory cytokines have this property (see Table 1).

\section{Gene delivery to cartilage defects}

For the gene-based delivery of certain growth factors or intracellular proteins, a strategy whereby the transgenes are more localized, and the gene products contained within the cartilage lesion, appears to be most prudent. Possibly, the most direct manner by which to achieve this goal is by implantation of a three-dimensional matrix pre-loaded with a gene delivery vehicle into a defect, allowing infiltrating cells to acquire the vector and locally secrete the stimulating transgene products $[18,48]$. Genetically activated implants have been designed to augment the healing of bones, ligaments and also cartilage $[17,34,48,140,141,150]$. For example, hydrated collagen-glycosaminoglycan matrices containing adenoviral vectors have been found to promote localized reporter gene expression in vivo, following implantation into osteochondral defects in rabbit knees, for at least 21 days [140]. However, given the usually limited cell supply at the cartilage lesion site, it is not yet known whether this type of approach can induce a sufficient biological response for repair. In order to increase the cellularity of the graft, while preserving the feasibility of the procedure within one operative setting, the genetically activated matrix could be mixed together with autologous cells, which are intraoperatively readily available, e.g. cells from bone marrow aspirates (Figure 1). Such an abbreviated, genetically enhanced tissue engineering approach would thus save time and costs, while avoiding laborintensive ex vivo culture of cells $[48,140]$. Their limitation, however, is the lack of control over gene transfer following implantation.

As there are several advantages, gene transfer has mostly been used to augment $e x$ vivo cell delivery approaches for cartilage repair (Figure 1). Such an approach delivers a pure population of cells, that can be selected under controlled conditions; the graft is highly cellular, localizes transgene expression to the injury site without administration of free vector, and there is the 
possibility for safety testing prior to transplantation. In the context of ex vivo gene delivery to cartilage defects, several experimental studies have been performed, exploring gene transfer to chondrocytes or mesenchymal progenitor cells.

\section{Gene transfer to chondrocytes}

A major advantage of using autologous chondrocytes as cell source for cartilage repair is that their application has already found the way out of the experimental stadium to clinical practice [20]. In recent years, autologous chondrocyte transplantation (ACT) has become a clinically adopted procedure for cartilage defects, especially when marrow stimulation techniques failed to generate good clinical results [145]. In order to further improve the quality of the repair tissue, attempts have been made to enhance this procedure by the use of genetically-modified chondrocytes. Although chondrocytes have been somewhat resistant to transfection with plasmid DNA, certain lipid-based formulations have been found to enhance the efficiency of DNA uptake [106]. Viral based vectors, however, are capable of generating far higher levels of transgene expression with greater persistence. Monolayer expanded chondrocytes are readily transduced by viral vectors, such as Moloney Murine Leukemia Virus (MLV), lentivirus, adenovirus and AAV. Adenoviral-mediated delivery of various transgenes, such as TGF- $\beta 1$, BMP-2, IGF-1 or BMP-7, has been shown to stimulate the production a cartilagespecific matrix rich in collagen type II and proteoglycans, and a decreased tendency towards dedifferentiation $[75,130,131,157,159]$. Transfer of cDNA encoding matrix molecules, such as the collagen type II minigene, led to enhanced extracellular matrix production of human fetal chondrocytes [37]. Transduction with the transcription factor SOX-9 increased collagen type II expression of chondrocytes in three-dimensional culture in vitro $[99,167]$, whereas overexpression of the transcription factor Runx-2 (Cbfa-1) stimulated chondrocyte maturation and induced a hypertrophic phenotype, expressing high levels of collagen types II and X, alkaline phosphatase and osteogenic marker genes [44,84].

Having shown that chondrocyte biology can be positively influenced by genetic modification, research focus has shifted towards their efficient delivery to cartilage lesions. The first approach would be the delivery of genetically modified chondrocytes in suspension. Several studies have shown that genetically modified chondrocytes are capable of expressing transgene products at functional levels following engraftment onto cartilage explants in vitro [42]. In such systems, genetic-modification with IGF-1 [107], FGF-2 [109], or SOX9 [33] led to significant resurfacing and thicker tissue enriched with proteoglycans and collagen type II, compared to transplanted control cells [106]. In addition, adenoviral-mediated IL-1Ra gene transfer to chondrocytes resulted in resistance to IL-1-induced proteoglycan degradation after engraftment [11]. As an alternative to delivery in suspension, efforts have also been made to augment tissue engineering procedures using genetically modified chondrocytes (Figure 1C). For this, the cells are transduced/transfected in monolayer and then seeded into a matrix for subsequent transplantation into chondral or osteochondral defects. In such three-dimensional culture systems, several transgenes have shown promising results in maintaining and promoting the chondrogenic phenotype in vitro, including TGF- $\beta 1$, BMP-2, -4, -7, IGF-1, SOX9 among others $[164,171,177]$.

Initial studies demonstrated that chondrocytes efficiently expressed reporter genes in chondral and osteochondral defects following genetic modifications with adenoviral, AAV, retroviral or plasmid vectors, and that transgene expression was prolonged for several weeks when the genetically-modified chondrocytes were seeded in three-dimensional matrices $[12,82,89$, 108]. Results of efficacy studies are just beginning to emerge, showing the effects of genetically modified chondrocytes in cartilage lesions in vivo (Table 3). In an ex vivo approach, adenovirally-transduced chondrocytes expressing BMP-7 [75], incorporated in a matrix of autogenous fibrin, were implanted into full thickness articular cartilage defects in horses [75]. 
Four weeks after surgery, an increased tissue volume and accelerated formation of a proteoglycan and collagen type II rich matrix could be observed in the BMP-7 treated defects compared to control defects treated with irrelevant marker genes. However, after 8 months, the levels of collagen type II and proteoglycan, and the mechanical characteristics of the treated defects compared to the controls were similar. This was attributed in part to the declining number of allografted chondrocytes that persisted in the defects after 8 months [75]. Nevertheless, it is encouraging that genetically modified chondrocytes can be used to augment a cartilage repair process in a large animal model.

\section{Gene transfer to mesenchymal stem cells}

The use of autologous chondrocytes for the repair of articular cartilage is limited, as they have to be isolated from a very limited supply of healthy non-weight-bearing articular cartilage, which has to be surgically removed, with the risk of donor site morbidity. Furthermore, chondrocytes dedifferentiate during expansion with a subsequent loss of the chondrocytic phenotype. With regard to cell- and gene-based approaches to cartilage repair, mesenchymal progenitor cells, also referred to as mesenchymal stem cells (MSCs), provide an attractive alternative to chondrocytes. Although no clear phenotype has been described, through the use of the proper culture conditions, expanded MSCs can be stimulated to differentiate along specific pathways such as chondrogenesis, adipogenesis, and osteogenesis $[23,25,26,28,86$, 92,134,135,146,175-177]. MSCs have been isolated from several sources, including bone marrow [147], trabecular bone chips [134], adipose tissue [198], periosteum, perichondrium and others, and have been shown to maintain their multilineage potential with passage in culture [195]. In order to harness MSCs for cartilage tissue engineering, analyses of the appropriate three-dimensional microenvironment to stimulate MSCs toward chondrogenesis in vitro und in vivo have been performed extensively, with factors such as TGF- $\beta 1,2,-3$, and BMP-2 emerging among the most popular candidates (see also Table 1). This research has led to the first clinical application of autologous bone marrow stromal cells for the repair of full-thickness articular cartilage defects in humans, which resulted in stable fibrocartilage tissue formation at the defect site [93,187]. However, a successful use of MSCs to aid cartilage repair by means of generating a stable hyaline-rich cartilage repair tissue in vivo, likely requires the efficient delivery of factors to stimulate MSCs toward chondrogenesis, and maintenance of an articular cartilage phenotype without ossification, fibrinogenesis, or inflammation $[23,80,177]$.

In order to meet these requirements, gene therapy approaches hold promise for efficient implementation in cartilage repair procedures. In this context, MSCs are readily transduced by recombinant adenoviral, retroviral, lentiviral, AAV $[24,57,195,196]$ and foamy viral vectors (A. Steinert and A. Rethwilm, unpublished observation). Specific liposomal formulations were used with some efficiency [69,106,107], as well as molecular vibration-based methods [160]. In vitro chondrogenesis has been shown, following plasmid-mediated BMP-2 and BMP-4 [1, 163], retrovirus-mediated BMP-2 [27], and adenovirus-mediated BMP-13 gene transfer in the murine mesenchymal progenitor cell line C3H10T1/2. Marrow-derived, primary mesenchymal progenitor cells, genetically modified to express TGF- $\beta 1$ or BMP- 2 , were also found to undergo chondrogenesis in aggregate culture, in contrast to IGF-1 modified cultures and reporter gene controls [196]. Interestingly, chondrogenesis in these cultures was also dependent on the level and duration of transgene expression and the viral load, indicating that these factors have to be carefully optimized for a successful in vivo translation of this technology [196].

Some first studies have been performed applying MSC-mediated gene delivery for cartilage repair in vivo. A variety of reporter genes have been successfully delivered to osteochondral defects via periosteal, perichondral or marrow derived MSCs [116,138,140,164,171]. Only a few studies have been conducted using therapeutic genes via MSCs thus far. 
A genetically enhanced tissue engineering approach used constructs fabricated of retrovirallytransduced periosteal cells expressing BMP-7, which were seeded into polyglycolic acid scaffolds before transplantation into rabbit osteochondral defects [116,117]. The defects treated with BMP-7 modified progenitors revealed improved regeneration tissue of cartilage and bone, compared to controls after a maximum of 12 weeks post-implantation. In a study using a similar experimental approach, genetically modified periosteal cells transduced to express sonic hedgehog $(\mathrm{SHH})$ were compared to the delivery of the BMP-7 cDNA, which resulted in a better overall repair of the SHH compared with the BMP-7 treated defects after 12 weeks postoperatively, and both were superior to marker gene controls [67]. Using the same animal model, constructs of a collagen type I hydrogel and marrow derived MSCs following liposomal GDF-5 (CDMP-1) gene delivery were shown to enhance cartilage repair compared with marker gene controls [90].

Another approach to study gene-induced chondrogenesis in vivo was devised by Gelse et al. who used gene transfer to MSCs for the repair of partial thickness cartilage lesions in rats [57]. The MSCs were isolated from rib perichondrium and, following adenoviral-modification with Ad.BMP-2 and Ad.IGF-1, delierved via a fibrin glue matrix to partial thickness cartilage lesions of the patellar groove. Both treatment with BMP-2 and with IGF-1 resulted in formation of improved repair tissue rich in collagen type II and proteoglycans, compared with the naïve and Ad.LacZ controls after 8 weeks [57]. However, the majority of BMP-2 treated joints showed signs of ectopic bone formation and osteophytes, which were not present in the knees of the IGF-1 treated defects [57].

In order to simplify elaborate and expensive ex vivo tissue engineering procedures, efforts are underway to facilitate gene delivery approaches to stimulate MSCs at the defect site in vivo toward chondrogenesis. The simplest way of achieving this aim is maybe via direct vector delivery to the cartilage defect site. Toward this end, direct application of recombinant AAV vectors in suspension [32], or of adenoviral vectors incorporated in hydrated collagenglycosaminoglycan matrices [140] have been found to promote localized transgene expression within the repair tissue formed, following transplantation into cartilage lesions in vivo. However, considerable vector leakage to adjacent synovium was observed [140]. In an attempt to augment this kind of approach with an autologous cellular and space-filling entity, Pascher and colleagues demonstrated that when fresh bone marrow aspirates were mixed with a solution of recombinant adenoviral vectors and allowed to coagulate, MSCs within the coagulum acquired and expressed the transgene for several weeks after implantation into osteochondral defects in rabbits [140]. Studies are underway to investigate how these advances can be harnessed to achieve cartilage repair.

\section{Challenges for gene therapy to promote cartilage repair}

Currently used cartilage repair approaches, both experimental and clinical, are still far from generating a repair tissue that is comparable to the native cartilage tissue quality and stability. To tackle various obstacles toward successful repair, including matrix degradation, differentiation or integration insufficiencies, or loss of the transplanted cells and tissues, efficient delivery of chondrogenic, anti-inflammatory, and anti-oxidative factors seems to be crucial (Table 1). As most of these factors are recombinant proteins, which have short half lives, a repeated local administration is likely to be necessary to achieve the desired result, thus presenting delivery problems. Gene transfer techniques might be adopted that could overcome the limitations of the current treatments for damaged articular cartilage. The current concepts in gene therapy for cartilage repair are reviewed here. Various approaches have been shown to be suited for efficient transfer of exogenous cDNAs to cartilage defects in vivo, and for achieving sustained expression of the corresponding gene products. Initial efficacy studies indicate that gene-transfer techniques are potent tools that can indeed stimulate a relevant 
biological response in vivo (Table 3). To date most approaches delivered a strong anabolic transgene aiming to achieve formation of a hyaline-like cartilage repair tissue in vivo, but with limited long-term success thus far. As more data surfaces, a clearer picture of the functional boundaries of current approaches appears. The future challenge therefore is to determine which combination of transgenes will be most suitable for which aspects of repair, and how best to deliver and express them.

Toward this end, the use of more refined vector systems seems to be crucial. Current gene transfer studies to cartilage repair have used vector systems with strong, viral-based promoters enabling very high levels of expression, thus facilitating study of the biological effects that may be achieved with a particular gene and gene delivery method. However it is likely that the stimulation of faithful synthesis of the complex architecture of articular cartilage, followed by its maintenance long-term will require the use of more sophisticated vector systems capable of coordinate control of expression. As many gene products proposed for use can have detrimental side effects if overexpressed in non-target organs such as the heart, lung or kidney, the characterization of the duration of expression in vivo and the biodistribution of vector and/ or genetically modified cells following delivery, will be critical. Toward this end, there are several types of cartilage-specific regulatory elements that have been characterized and that might be incorporated into gene delivery systems, such as promoters for the cartilage-derived retinoic acid-sensitive protein (CD-RAP), the procollagen type II $\alpha 1$ (COL2A1), or the aggrecan gene $[96,100,127,128,158,173,180,191,197]$.

Because cartilage injuries are not life-threatening, the safety of gene transfer approaches for repair is of particular importance. To harness the potential of this technology for clinical use is therefore strongly dependent on the use of safe and efficient vectors, transgenes and delivery systems.

\section{Acknowledgments}

This work is supported by the Deutsche Forschungsgemeinschaft (DFG STE1051/2-1 to A.F.S. and U.N) and the Interdisziplinäres Zentrum für Klinische Forschung (IZKF D-23/1 to. A.F.S), and the Intramural Research Program of the National Institute of Arthritis, and Musculoskeletal and Skin Diseases, NIH (Z01 AR 41131). We apologize to investigators whose work could not be cited due to space limitations.

\section{References}

1. Ahrens M, Ankenbauer T, Schroder D, et al. Expression of human bone morphogenetic proteins-2 or -4 in murine mesenchymal progenitor $\mathrm{C} 3 \mathrm{H} 10 \mathrm{~T} 1 / 2$ cells induces differentiation into distinct mesenchymal cell lineages. DNA Cell Biol 1993;12(10):871-880. [PubMed: 8274220]

2. Alaaeddine N, Di Battista JA, Pelletier JP, et al. Differential effects of IL-8, LIF (pro-inflammatory) and IL-11 (anti-inflammatory) on TNF-alpha-induced PGE(2)release and on signalling pathways in human OA synovial fibroblasts. Cytokine 1999;11(12):1020-1030. [PubMed: 10623427]

3. Alaaeddine N, Di Battista JA, Pelletier JP, et al. Inhibition of tumor necrosis factor alpha-induced prostaglandin E2 production by the antiinflammatory cytokines interleukin-4, interleukin-10, and interleukin-13 in osteoarthritic synovial fibroblasts: distinct targeting in the signaling pathways. Arthritis Rheum 1999;42(4):710-718. [PubMed: 10211885]

4. Apparailly F, Verwaerde C, Jacquet C, et al. Adenovirus-mediated transfer of viral IL-10 gene inhibits murine collagen-induced arthritis. J Immunol 1998;160(11):5213-5220. [PubMed: 9605116]

5. Apparailly F, Millet V, Noel D, et al. Tetracycline-inducible interleukin-10 gene transfer mediated by an adeno-associated virus: application to experimental arthritis. Hum Gene Ther 2002;13(10):11791188. [PubMed: 12133271]

6. Arai Y, Kubo T, Kobayashi K, et al. Adenovirus vector-mediated gene transduction to chondrocytes: in vitro evaluation of therapeutic efficacy of transforming growth factor-beta 1 and heat shock protein 70 gene transduction. J Rheumatol 1997;24(9):1787-1795. [PubMed: 9292805] 
7. Ataliotis P. Platelet-derived growth factor A modulates limb chondrogenesis both in vivo and in vitro. Mech Dev 2000;94(12):13-24. [PubMed: 10842055]

8. Bakker AC, Joosten LA, Arntz OJ, et al. Prevention of murine collagen-induced arthritis in the knee and ipsilateral paw by local expression of human interleukin-1 receptor antagonist protein in the knee. Arthritis Rheum 1997;40(5):893-900. [PubMed: 9153551]

9. Baltzer AW, Lieberman JR. Regional gene therapy to enhance bone repair. Gene Ther 2004;11(4): 344-350. [PubMed: 14724686]

10. Bandara G, Mueller GM, Galea-Lauri J, et al. Intraarticular expression of biologically active interleukin 1-receptor- antagonist protein by ex vivo gene transfer. Proc Natl Acad Sci U S A 1993;90 (22):10764-10768. [PubMed: 8248169]

11. Baragi VM, Renkiewicz RR, Jordan H, et al. Transplantation of transduced chondrocytes protects articular cartilage from interleukin 1-induced extracellular matrix degradation. J Clin Invest 1995;96 (5):2454-2460. [PubMed: 7593634]

12. Baragi VM, Renkiewicz RR, Qiu L, et al. Transplantation of adenovirally transduced allogeneic chondrocytes into articular cartilage defects in vivo. Osteoarthritis Cartilage 1997;5(4):275-282. [PubMed: 9404472]

13. Barre L, Venkatesan N, Magdalou J, et al. Evidence of calcium-dependent pathway in the regulation of human beta1,3-glucuronosyltransferase-1 (GlcAT-I) gene expression: a key enzyme in proteoglycan synthesis. Faseb J 2006;20(10):1692-1694. [PubMed: 16807373]

14. Barry F, Boynton RE, Liu B, et al. Chondrogenic differentiation of mesenchymal stem cells from bone marrow: differentiation-dependent gene expression of matrix components. Exp Cell Res 2001;268(2):189-200. [PubMed: 11478845]

15. Behrens P, Bosch U, Bruns J, et al. [Indications and implementation of recommendations of the working group "Tissue Regeneration and Tissue Substitutes" for autologous chondrocyte transplantation (ACT)]. Z Orthop Ihre Grenzgeb 2004;142(5):529-539. [PubMed: 15472761]

16. Blanco FJ, Geng Y, Lotz M. Differentiation-dependent effects of IL-1 and TGF-beta on human articular chondrocyte proliferation are related to inducible nitric oxide synthase expression. $\mathrm{J}$ Immunol 1995;154(8):4018-4026. [PubMed: 7535818]

17. Bonadio J, Smiley E, Patil P, et al. Localized, direct plasmid gene delivery in vivo: prolonged therapy results in reproducible tissue regeneration [see comments]. Nat Med 1999;5(7):753-759. [PubMed: 10395319]

18. Bonadio J. Tissue engineering via local gene delivery: update and future prospects for enhancing the technology. Adv Drug Deliv Rev 2000;44(23):185-194. [PubMed: 11072114]

19. Bouwmeester SJ, Beckers JM, Kuijer R, et al. Long-term results of rib perichondrial grafts for repair of cartilage defects in the human knee. Int Orthop 1997;21(5):313-317. [PubMed: 9476161]

20. Brittberg M, Lindahl A, Nilsson A, et al. Treatment of deep cartilage defects in the knee with autologous chondrocyte transplantation. N Engl J Med 1994;331(14):889-895. [PubMed: 8078550]

21. Buckwalter JA. Articular cartilage: injuries and potential for healing. J Orthop Sports Phys Ther 1998;28(4):192-202. [PubMed: 9785255]

22. Buckwalter JA, Mankin HJ. Articular cartilage repair and transplantation. Arthritis Rheum 1998;41 (8):1331-1342. [PubMed: 9704631]

23. Caplan AI, Elyaderani M, Mochizuki Y, et al. Principles of cartilage repair and regeneration. Clin Orthop 1997;342:254-269. [PubMed: 9308548]

24. Caplan AI. Mesenchymal stem cells and gene therapy. Clin Orthop 2000;(379 Suppl):S67-70. [PubMed: 11039754]

25. Caplan AI, Bruder SP. Mesenchymal stem cells: building blocks for molecular medicine in the $21 \mathrm{st}$ century. Trends Mol Med 2001;7(6):259-264. [PubMed: 11378515]

26. Caplan AI, Dennis JE. Mesenchymal stem cells as trophic mediators. J Cell Biochem 2006;98(5): 1076-1084. [PubMed: 16619257]

27. Carlberg AL, Pucci B, Rallapalli R, et al. Efficient chondrogenic differentiation of mesenchymal cells in micromass culture by retroviral gene transfer of BMP-2. Differentiation 2001;67(45):128-138. [PubMed: 11683496]

28. Chen FH, Rousche KT, Tuan RS. Technology Insight: adult stem cells in cartilage regeneration and tissue engineering. Nat Clin Pract Rheumatol 2006;2(7):373-382. [PubMed: 16932723] 
29. Chernajovsky Y, Adams G, Podhajcer OL, et al. Inhibition of transfer of collagen-induced arthritis into SCID mice by ex vivo infection of spleen cells with retroviruses expressing soluble tumor necrosis factor receptor. Gene Ther 1995;2(10):731-735. [PubMed: 8750012]

30. Conway JG, Andrews RC, Beaudet B, et al. Inhibition of tumor necrosis factor-alpha (TNF-alpha) production and arthritis in the rat by GW3333, a dual inhibitor of TNF-alpha-converting enzyme and matrix metalloproteinases. J Pharmacol Exp Ther 2001;298(3):900-908. [PubMed: 11504783]

31. Cucchiarini M, Madry H. Gene therapy for cartilage defects. J Gene Med 2005;7(12):1495-1509. [PubMed: 16142829]

32. Cucchiarini M, Madry H, Ma C, et al. Improved tissue repair in articular cartilage defects in vivo by rAAV-mediated overexpression of human fibroblast growth factor 2. Mol Ther 2005;12(2):229-238. [PubMed: 16043094]

33. Cucchiarini M, Thurn T, Weimer A, et al. Restoration of the extracellular matrix in human osteoarthritic articular cartilage by overexpression of the transcription factor SOX9. Arthritis Rheum 2007;56(1):158-167. [PubMed: 17195218]

34. Dai Q, Manfield L, Wang Y, et al. Adenovirus-mediated gene transfer to healing tendon-enhanced efficiency using a gelatin sponge. J Orthop Res 2003:21604-609.

35. Dayer JM. Interleukin 1 or tumor necrosis factor-alpha: which is the real target in rheumatoid arthritis? J Rheumatol Suppl 2002:6510-15.

36. Denker AE, Haas AR, Nicoll SB, et al. Chondrogenic differentiation of murine C3H10T1/2 multipotential mesenchymal cells: I. Stimulation by bone morphogenetic protein-2 in high-density micromass cultures. Differentiation 1999;64(2):67-76. [PubMed: 10234804]

37. Dharmavaram RM, Liu G, Tuan RS, et al. Stable transfection of human fetal chondrocytes with a type II procollagen minigene: expression of the mutant protein and alterations in the structure of the extracellular matrix in vitro. Arthritis Rheum 1999;42(7):1433-1442. [PubMed: 10403271]

38. Di Cesare PE, Frenkel SR, Carlson CS, et al. Regional gene therapy for full-thickness articular cartilage lesions using naked DNA with a collagen matrix. J Orthop Res 2006;24(5):1118-1127. [PubMed: 16609967]

39. D'Lima DD, Hashimoto S, Chen PC, et al. Impact of mechanical trauma on matrix and cells. Clin Orthop Relat Res 2001;(391 Suppl):S90-99. [PubMed: 11603728]

40. D'Lima DD, Hashimoto S, Chen PC, et al. Prevention of chondrocyte apoptosis. J Bone Joint Surg Am 2001;83-A(Pt 1):25-26. [PubMed: 11685840]

41. D'Lima DD, Hashimoto S, Chen PC, et al. Cartilage injury induces chondrocyte apoptosis. J Bone Joint Surg Am 2001;83-A(Pt 1):19-21. [PubMed: 11685837]

42. Doherty PJ, Zhang H, Tremblay L, et al. Resurfacing of articular cartilage explants with geneticallymodified human chondrocytes in vitro. Osteoarthritis Cartilage 1998;6(3):153-159. [PubMed: 9682781]

43. Ebert R, Ulmer M, Zeck S, et al. Selenium supplementation restores the antioxidative capacity and prevents cell damage in bone marrow stromal cells in vitro. Stem Cells 2006;24(5):1226-1235. [PubMed: 16424399]

44. Enomoto H, Enomoto-Iwamoto M, Iwamoto M, et al. Cbfa1 is a positive regulatory factor in chondrocyte maturation. J Biol Chem 2000;275(12):8695-8702. [PubMed: 10722711]

45. Erdmann S, Muller W, Bahrami S, et al. Differential effects of parathyroid hormone fragments on collagen gene expression in chondrocytes. J Cell Biol 1996;135(4):1179-1191. [PubMed: 8922395]

46. Evans CH, Robbins PD, Ghivizzani SC, et al. Clinical trial to assess the safety, feasibility, and efficacy of transferring a potentially anti-arthritic cytokine gene to human joints with rheumatoid arthritis. Hum Gene Ther 1996;7(10):1261-1280. [PubMed: 8793551]

47. Evans CH, Gouze JN, Gouze E, et al. Osteoarthritis gene therapy. Gene Ther 2004;11(4):379-389. [PubMed: 14724685]

48. Evans, CH.; Pascher, A.; Betz, O., et al. Genetically enhanced tissue engineering without cell culture or artificial scaffolds. In: Grodzinsky, AJ.; Sandell, L., editors. Orthopaedic Tissue Engineering. Rosemont, ILL: AAOS; 2004. p. 389-394.

49. Evans CH, Robbins PD, Ghivizzani SC, et al. Gene transfer to human joints: progress toward a gene therapy of arthritis. Proc Natl Acad Sci U S A 2005;102(24):8698-8703. [PubMed: 15939878] 
50. Evans CH, Gouze E, Gouze JN, et al. Gene therapeutic approaches-transfer in vivo. Adv Drug Deliv Rev 2006;58(2):243-258. [PubMed: 16563557]

51. Fischer L, Boland G, Tuan RS. Wnt-3A enhances bone morphogenetic protein-2-mediated chondrogenesis of murine C3H10T1/2 mesenchymal cells. J Biol Chem 2002;277(34):30870-30878. [PubMed: 12077113]

52. Fleischmann RM, Schechtman J, Bennett R, et al. Anakinra, a recombinant human interleukin-1 receptor antagonist (r-metHuIL-1ra), in patients with rheumatoid arthritis: A large, international, multicenter, placebo-controlled trial. Arthritis Rheum 2003;48(4):927-934. [PubMed: 12687534]

53. Fortier LA, Mohammed HO, Lust G, et al. Insulin-like growth factor-I enhances cell-based repair of articular cartilage. J Bone Joint Surg Br 2002;84(2):276-288. [PubMed: 11922373]

54. Frisbie DD, Ghivizzani SC, Robbins PD, et al. Treatment of experimental equine osteoarthritis by in vivo delivery of the equine interleukin-1 receptor antagonist gene. Gene Ther 2002;9(1):12-20. [PubMed: 11850718]

55. Fukumoto T, Sperling JW, Sanyal A, et al. Combined effects of insulin-like growth factor-1 and transforming growth factor-betal on periosteal mesenchymal cells during chondrogenesis in vitro. Osteoarthritis Cartilage 2003;11(1):55-64. [PubMed: 12505488]

56. Gelse K, Jiang QJ, Aigner T, et al. Fibroblast-mediated delivery of growth factor complementary DNA into mouse joints induces chondrogenesis but avoids the disadvantages of direct viral gene transfer. Arthritis Rheum 2001;44(8):1943-1953. [PubMed: 11508447]

57. Gelse K, von der Mark K, Aigner T, et al. Articular cartilage repair by gene therapy using growth factor-producing mesenchymal cells. Arthritis Rheum 2003;48(2):430-441. [PubMed: 12571853]

58. Gelse K, Schneider H. Ex vivo gene therapy approaches to cartilage repair. Adv Drug Deliv Rev 2006;58(2):259-284. [PubMed: 16574266]

59. Ghivizzani SC, Kang R, Georgescu HI, et al. Constitutive intra-articular expression of human IL-1 beta following gene transfer to rabbit synovium produces all major pathologies of human rheumatoid arthritis. J Immunol 1997;159(7):3604-3612. [PubMed: 9317160]

60. Ghivizzani SC, Lechman ER, Kang R, et al. Direct adenovirus-mediated gene transfer of interleukin 1 and tumor necrosis factor alpha soluble receptors to rabbit knees with experimental arthritis has local and distal anti-arthritic effects. Proc Natl Acad Sci U S A 1998;95(8):4613-4618. [PubMed: 9539786]

61. Ghivizzani SC, Oligino TJ, Glorioso JC, et al. Direct gene delivery strategies for the treatment rheumatoid arthritis. Drug Discovery Today 2001;6(5):236-244.

62. Gouze E, Pawliuk R, Pilapil C, et al. In vivo gene delivery to synovium by lentiviral vectors. Mol Ther 2002;5(4):397-404. [PubMed: 11945066]

63. Gouze E, Pawliuk R, Gouze JN, et al. Lentiviral-mediated gene delivery to synovium: potent intraarticular expression with amplification by inflammation. Mol Ther 2003;7(4):460-466. [PubMed: 12727108]

64. Gouze JN, Gouze E, Palmer GD, et al. A comparative study of the inhibitory effects of interleukin-1 receptor antagonist following administration as a recombinant protein or by gene transfer. Arthritis Res Ther 2003;5(5):R301-309. [PubMed: 12932294]

65. Gouze JN, Gouze E, Palmer GD, et al. Adenovirus-mediated gene transfer of glutamine: fructose-6phosphate amidotransferase antagonizes the effects of interleukin-1beta on rat chondrocytes. Osteoarthritis Cartilage 2004;12(3):217-224. [PubMed: 14972338]

66. Gouze JN, Stoddart MJ, Gouze E, et al. In vitro gene transfer to chondrocytes and synovial fibroblasts by adenoviral vectors. Methods Mol Med 2004:100147-164.

67. Grande DA, Mason J, Light E, et al. Stem cells as platforms for delivery of genes to enhance cartilage repair. J Bone Joint Surg Am 2003:2111-116. [PubMed: 14630839]

68. Gruber R, Mayer C, Bobacz K, et al. Effects of cartilage-derived morphogenetic proteins and osteogenic protein-1 on osteochondrogenic differentiation of periosteum-derived cells. Endocrinology 2001;142(5):2087-2094. [PubMed: 11316776]

69. Haleem-Smith H, Derfoul A, Okafor C, et al. Optimization of high-efficiency transfection of adult human mesenchymal stem cells in vitro. Mol Biotechnol 2005;30(1):9-20. [PubMed: 15805572]

70. Hanada K, Solchaga LA, Caplan AI, et al. BMP-2 induction and TGF-beta 1 modulation of rat periosteal cell chondrogenesis. J Cell Biochem 2001;81(2):284-294. [PubMed: 11241668] 
71. Hangody L, Fules P. Autologous osteochondral mosaicplasty for the treatment of full-thickness defects of weight-bearing joints: ten years of experimental and clinical experience. J Bone Joint Surg Am 2003;85-A:225-32.

72. Hannallah D, Peng H, Young B, et al. Retroviral delivery of Noggin inhibits the formation of heterotopic ossification induced by BMP-4, demineralized bone matrix, and trauma in an animal model. J Bone Joint Surg Am 2004;86-A(1):80-91. [PubMed: 14711949]

73. Haupt JL, Frisbie DD, McIlwraith CW, et al. Dual transduction of insulin-like growth factor-I and interleukin-1 receptor antagonist protein controls cartilage degradation in an osteoarthritic culture model. J Orthop Res 2005;23(1):118-126. [PubMed: 15607883]

74. Hickey DG, Frenkel SR, Di Cesare PE. Clinical applications of growth factors for articular cartilage repair. Am J Orthop 2003;32(2):70-76. [PubMed: 12602635]

75. Hidaka C, Goodrich LR, Chen CT, et al. Acceleration of cartilage repair by genetically modified chondrocytes over expressing bone morphogenetic protein-7. J Orthop Res 2003;21(4):573-583. [PubMed: 12798054]

76. Hoffmann A, Gross G. BMP signaling pathways in cartilage and bone formation. Crit Rev Eukaryot Gene Expr 2001;11(13):23-45. [PubMed: 11693963]

77. Hoffmann A, Czichos S, Kaps C, et al. The T-box transcription factor Brachyury mediates cartilage development in mesenchymal stem cell line C3H10T1/2. J Cell Sci 2002;115(Pt 4):769-781. [PubMed: 11865033]

78. Holler N, Kataoka T, Bodmer JL, et al. Development of improved soluble inhibitors of FasL and CD40L based on oligomerized receptors. J Immunol Methods 2000;237(12):159-173. [PubMed: 10725460]

79. Holler N, Zaru R, Micheau O, et al. Fas triggers an alternative, caspase-8-independent cell death pathway using the kinase RIP as effector molecule. Nat Immunol 2000;1(6):489-495. [PubMed: 11101870]

80. Hunziker EB. Articular cartilage repair: basic science and clinical progress. A review of the current status and prospects. Osteoarthritis Cartilage 2002;10(6):432-463. [PubMed: 12056848]

81. Hwang SG, Ryu JH, Kim IC, et al. Wnt-7a causes loss of differentiated phenotype and inhibits apoptosis of articular chondrocytes via different mechanisms. J Biol Chem 2004;279(25):2659726604. [PubMed: 15082716]

82. Ikeda T, Kubo T, Arai Y, et al. Adenovirus mediated gene delivery to the joints of guinea pigs. J Rheumatol 1998;25(9):1666-1673. [PubMed: 9733444]

83. Ito Y, Bringas P Jr, Mogharei A, et al. Receptor-regulated and inhibitory Smads are critical in regulating transforming growth factor beta-mediated Meckel's cartilage development. Dev Dyn 2002;224(1):69-78. [PubMed: 11984875]

84. Iwamoto M, Kitagaki J, Tamamura Y, et al. Runx2 expression and action in chondrocytes are regulated by retinoid signaling and parathyroid hormone-related peptide (PTHrP). Osteoarthritis Cartilage 2003;11(1):6-15. [PubMed: 12505482]

85. Iwasaki M, Jikko A, Le AX. Age-dependent effects of hedgehog protein on chondrocytes. J Bone Joint Surg Br 1999;81(6):1076-1082. [PubMed: 10615989]

86. Jiang Y, Jahagirdar BN, Reinhardt RL, et al. Pluripotency of mesenchymal stem cells derived from adult marrow. Nature 2002;418(6893):41-49. [PubMed: 12077603]

87. Jorgensen C, Apparailly F, Couret I, et al. Interleukin-4 and interleukin-10 are chondroprotective and decrease mononuclear cell recruitment in human rheumatoid synovium in vivo. Immunology 1998;93 (4):518-523. [PubMed: 9659224]

88. Kafienah W, Al-Fayez F, Hollander AP, et al. Inhibition of cartilage degradation: a combined tissue engineering and gene therapy approach. Arthritis Rheum 2003;48(3):709-718. [PubMed: 12632424]

89. Kang R, Marui T, Ghivizzani SC, et al. Ex vivo gene transfer to chondrocytes in full-thickness articular cartilage defects: a feasibility study. Osteoarthritis Cartilage 1997;5(2):139-143. [PubMed: 9135825]

90. Katayama R, Wakitani S, Tsumaki N, et al. Repair of articular cartilage defects in rabbits using CDMP1 gene-transfected autologous mesenchymal cells derived from bone marrow. Rheumatology (Oxford) 2004;43(8):980-985. [PubMed: 15187242] 
91. Kaul G, Cucchiarini M, Arntzen D, et al. Local stimulation of articular cartilage repair by transplantation of encapsulated chondrocytes overexpressing human fibroblast growth factor 2 (FGF-2) in vivo. J Gene Med 2006;8(1):100-111. [PubMed: 16097039]

92. Kuo CK, Li WJ, Mauck RL, et al. Cartilage tissue engineering: its potential and uses. Curr Opin Rheumatol 2006;18(1):64-73. [PubMed: 16344621]

93. Kuroda R, Ishida K, Matsumoto T, et al. Treatment of a full-thickness articular cartilage defect in the femoral condyle of an athlete with autologous bone-marrow stromal cells. Osteoarthritis Cartilage. 2006

94. Lechman ER, Jaffurs D, Ghivizzani SC, et al. Direct adenoviral gene transfer of viral IL-10 to rabbit knees with experimental arthritis ameliorates disease in both injected and contralateral control knees. J Immunol 1999;163(4):2202-2208. [PubMed: 10438962]

95. Lee KH, Song SU, Hwang TS, et al. Regeneration of hyaline cartilage by cell-mediated gene therapy using transforming growth factor beta 1-producing fibroblasts. Hum Gene Ther 2001;12(14):18051813. [PubMed: 11560773]

96. Lefebvre V, Mukhopadhyay K, Zhou G, et al. A 47-bp sequence of the first intron of the mouse pro alpha 1(II) collagen gene is sufficient to direct chondrocyte Expression. Ann N Y Acad Sci 1996:785284-287.

97. Lefebvre V, Li P, de Crombrugghe B. A new long form of Sox5 (L-Sox5), Sox6 and Sox9 are coexpressed in chondrogenesis and cooperatively activate the type II collagen gene. Embo J 1998;17 (19):5718-5733. [PubMed: 9755172]

98. Lefebvre V, Behringer RR, de Crombrugghe B. L-Sox5, Sox6 and Sox 9 control essential steps of the chondrocyte differentiation pathway. Osteoarthritis Cartilage 2001:AS69-75.

99. Li Y, Tew SR, Russell AM, et al. Transduction of passaged human articular chondrocytes with adenoviral, retroviral, and lentiviral vectors and the effects of enhanced expression of SOX9. Tissue Eng 2004;10(34):575-584. [PubMed: 15165474]

100. Lian JB, Stein GS, Stein JL, et al. Marrow transplantation and targeted gene therapy to the skeleton. Clin Orthop Relat Res 2000;(379 Suppl):S146-155. [PubMed: 11039763]

101. Lotz M. The role of nitric oxide in articular cartilage damage. Rheum Dis Clin North Am 1999;25 (2):269-282. [PubMed: 10356417]

102. Lotz M, Hashimoto S, Kuhn K. Mechanisms of chondrocyte apoptosis. Osteoarthritis Cartilage 1999;7(4):389-391. [PubMed: 10419776]

103. Lotz M. Cytokines in cartilage injury and repair. Clin Orthop Relat Res 2001;(391 Suppl):S108115. [PubMed: 11603695]

104. Lubberts E, Joosten LA, van Den Bersselaar L, et al. Adenoviral vector-mediated overexpression of IL-4 in the knee joint of mice with collagen-induced arthritis prevents cartilage destruction. J Immunol 1999;163(8):4546-4556. [PubMed: 10510398]

105. Lubberts E, Joosten LA, Van Den Bersselaar L, et al. Intra-articular IL-10 gene transfer regulates the expression of collagen-induced arthritis (CIA) in the knee and ipsilateral paw. Clin Exp Immunol 2000;120(2):375-383. [PubMed: 10792391]

106. Madry H, Trippel SB. Efficient lipid-mediated gene transfer to articular chondrocytes. Gene Ther 2000;7(4):286-291. [PubMed: 10694808]

107. Madry H, Zurakowski D, Trippel SB. Overexpression of human insulin-like growth factor-I promotes new tissue formation in an ex vivo model of articular chondrocyte transplantation. Gene Ther 2001;8(19):1443-1449. [PubMed: 11593356]

108. Madry H, Cucchiarini M, Stein U, et al. Sustained transgene expression in cartilage defects in vivo after transplantation of articular chondrocytes modified by lipid-mediated gene transfer in a gel suspension delivery system. J Gene Med 2003;5(6):502-509. [PubMed: 12797115]

109. Madry H, Emkey G, Zurakowski D, et al. Overexpression of human fibroblast growth factor 2 stimulates cell proliferation in an ex vivo model of articular chondrocyte transplantation. J Gene Med 2004;6(2):238-245. [PubMed: 14978777]

110. Madry H, Kaul G, Cucchiarini M, et al. Enhanced repair of articular cartilage defects in vivo by transplanted chondrocytes overexpressing insulin-like growth factor I (IGF-I). Gene Ther 2005;12 (15):1171-1179. [PubMed: 15815701] 
111. Maier R, Ganu V, Lotz M. Interleukin-11, an inducible cytokine in human articular chondrocytes and synoviocytes, stimulates the production of the tissue inhibitor of metalloproteinases. J Biol Chem 1993;268(29):21527-21532. [PubMed: 8408003]

112. Maier R, Bilbe G, Rediske J, et al. Inducible nitric oxide synthase from human articular chondrocytes: cDNA cloning and analysis of mRNA expression. Biochim Biophys Acta 1994;1208(1):145-150. [PubMed: 7522054]

113. Makarov SS, Olsen JC, Johnston WN, et al. Suppression of experimental arthritis by gene transfer of interleukin 1 receptor antagonist cDNA. Proc Natl Acad Sci U S A 1996;93(1):402-406. [PubMed: 8552648]

114. Marlovits S, Zeller P, Singer P, et al. Cartilage repair: generations of autologous chondrocyte transplantation. Eur J Radiol 2006;57(1):24-31. [PubMed: 16188417]

115. Martin JA, Klingelhutz AJ, Moussavi-Harami F, et al. Effects of oxidative damage and telomerase activity on human articular cartilage chondrocyte senescence. J Gerontol A Biol Sci Med Sci 2004;59(4):324-337. [PubMed: 15071075]

116. Mason JM, Grande DA, Barcia M, et al. Expression of human bone morphogenic protein 7 in primary rabbit periosteal cells: potential utility in gene therapy for osteochondral repair. Gene Ther 1998;5 (8):1098-1104. [PubMed: 10326033]

117. Mason JM, Breitbart AS, Barcia M, et al. Cartilage and bone regeneration using gene-enhanced tissue engineering [In Process Citation]. Clin Orthop 2000;(379 Suppl):S171-178. [PubMed: 11039767]

118. Merritt TM, Alcorn JL, Haynes R, et al. Expression of mutant cartilage oligomeric matrix protein in human chondrocytes induces the pseudoachondroplasia phenotype. J Orthop Res 2006;24(4): 700-707. [PubMed: 16514635]

119. Mi Z, Ghivizzani SC, Lechman ER, et al. Adenovirus-mediated gene transfer of insulin-like growth factor 1 stimulates proteoglycan synthesis in rabbit joints. Arthritis Rheum 2000;43(11):2563-2570. [PubMed: 11083281]

120. Mi Z, Ghivizzani SC, Lechman E, et al. Adverse effects of adenovirus-mediated gene transfer of human transforming growth factor beta 1 into rabbit knees. Arthritis Res Ther 2003;5(3):R132139. [PubMed: 12723985]

121. Minas T, Nehrer S. Current concepts in the treatment of articular cartilage defects. Orthopedics 1997;20(6):525-538. [PubMed: 9195635]

122. Minas T. The role of cartilage repair techniques, including chondrocyte transplantation, in focal chondral knee damage. Instr Course Lect 1999:48629-643.

123. Minas T, Peterson L. Advanced techniques in autologous chondrocyte transplantation. Clin Sports Med 1999;18(1):13-44. v-vi. [PubMed: 10028115]

124. Minina E, Wenzel HM, Kreschel C, et al. BMP and Ihh/PTHrP signaling interact to coordinate chondrocyte proliferation and differentiation. Development 2001;128(22):4523-4534. [PubMed: 11714677]

125. Miura T, Mattson MP, Rao MS. Cellular lifespan and senescence signaling in embryonic stem cells. Aging Cell 2004;3(6):333-343. [PubMed: 15569350]

126. Muller-Ladner U, Evans CH, Franklin BN, et al. Gene transfer of cytokine inhibitors into human synovial fibroblasts in the SCID mouse model. Arthritis Rheum 1999;42(3):490-497. [PubMed: 10088772]

127. Naski MC, Colvin JS, Coffin JD, et al. Repression of hedgehog signaling and BMP4 expression in growth plate cartilage by fibroblast growth factor receptor 3. Development 1998;125(24):49774988. [PubMed: 9811582]

128. Naski MC, Ornitz DM. FGF signaling in skeletal development. Front Biosci 1998:3d781-794.

129. Neumann E, Judex M, Kullmann F, et al. Inhibition of cartilage destruction by double gene transfer of IL-1Ra and IL-10 involves the activin pathway. Gene Ther 2002;9(22):1508-1519. [PubMed: 12407423]

130. Nixon AJ, Fortier LA, Williams J, et al. Enhanced repair of extensive articular defects by insulinlike growth factor-I-laden fibrin composites. J Orthop Res 1999;17(4):475-487. [PubMed: 10459752] 
131. Nixon AJ, Saxer RA, Brower-Toland BD. Exogenous insulin-like growth factor-I stimulates an autoinductive IGF-I autocrine/paracrine response in chondrocytes. J Orthop Res 2001;19(1):2632. [PubMed: 11332617]

132. Nixon AJ, Haupt JL, Frisbie DD, et al. Gene-mediated restoration of cartilage matrix by combination insulin-like growth factor-I/interleukin-1 receptor antagonist therapy. Gene Ther 2005;12(2):177186. [PubMed: 15578043]

133. Nochi H, Sung JH, Lou J, et al. Adenovirus mediated BMP-13 gene transfer induces chondrogenic differentiation of murine mesenchymal progenitor cells. J Bone Miner Res 2004;19(1):111-122. [PubMed: 14753743]

134. Noth U, Osyczka AM, Tuli R, et al. Multilineage mesenchymal differentiation potential of human trabecular bone-derived cells. J Orthop Res 2002;20(5):1060-1069. [PubMed: 12382974]

135. Noth U, Tuli R, Osyczka AM, et al. In vitro engineered cartilage constructs produced by presscoating biodegradable polymer with human mesenchymal stem cells. Tissue Eng 2002;8(1):131144. [PubMed: 11886661]

136. Oligino TJ, Yao Q, Ghivizzani SC, et al. Vector systems for gene transfer to joints. Clin Orthop 2000;(379 Suppl):S17-30. [PubMed: 11039748]

137. Oligino TJ, Ghivizzani SC, Wolfe D, et al. Intra-articular delivery of a herpes simplex virus IL-1Ra gene vector reduces inflammation in a rabbit model of arthritis. Gene Ther 1999;6(10):1713-1720. [PubMed: 10516720]

138. Palmer GD, Steinert A, Pascher A, et al. Gene-induced chondrogenesis of primary mesenchymal stem cells in vitro. Mol Therapy 2005;12(2):219-228.

139. Park J, Gelse K, Frank S, et al. Transgene-activated mesenchymal cells for articular cartilage repair: a comparison of primary bone marrow-, perichondrium/periosteum- and fat-derived cells. J Gene Med 2006;8(1):112-125. [PubMed: 16142704]

140. Pascher A, Palmer GD, Steinert AF, et al. Gene delivery to cartilage defects using coagulated bone marrow aspirate. Gene Ther 2004;11(2):133-141. [PubMed: 14712297]

141. Pascher A, Steinert AF, Palmer GD, et al. Enhanced repair of the anterior cruciate ligament by in situ gene transfer: evaluation in an in vitro model. Mol Ther 2004;10(2):327-336. [PubMed: 15294179]

142. Pathi S, Rutenberg JB, Johnson RL, et al. Interaction of Ihh and BMP/Noggin signaling during cartilage differentiation. Dev Biol 1999;209(2):239-253. [PubMed: 10328918]

143. Pelletier JP, Caron JP, Evans C, et al. In vivo suppression of early experimental osteoarthritis by interleukin- 1 receptor antagonist using gene therapy. Arthritis Rheum 1997;40(6):1012-1019. [PubMed: 9182910]

144. Peterson L, Brittberg M, Kiviranta I, et al. Autologous chondrocyte transplantation. Biomechanics and long-term durability. Am J Sports Med 2002;30(1):2-12. [PubMed: 11798989]

145. Peterson L, Minas T, Brittberg M, et al. Treatment of osteochondritis dissecans of the knee with autologous chondrocyte transplantation: results at two to ten years. J Bone Joint Surg Am 2003:21724.

146. Pittenger MF, Mackay AM, Beck SC, et al. Multilineage potential of adult human mesenchymal stem cells. Science 1999;284(5411):143-147. [PubMed: 10102814]

147. Prockop DJ, Sekiya IColter DC. Isolation and characterization of rapidly self-renewing stem cells from cultures of human marrow stromal cells. Cytotherapy 2001;3(5):393-396. [PubMed: 11953019]

148. Robbins PD, Evans CH, Chernajovsky Y. Gene therapy for arthritis. Gene Ther 2003;10(10):902911. [PubMed: 12732875]

149. Rudolphi K, Gerwin N, Verzijl N, et al. Pralnacasan, an inhibitor of interleukin-1beta converting enzyme, reduces joint damage in two murine models of osteoarthritis. Osteoarthritis Cartilage 2003;11(10):738-746. [PubMed: 13129693]

150. Samuel RE, Lee CR, Ghivizzani SC, et al. Delivery of plasmid DNA to articular chondrocytes via novel collagen-glycosaminoglycan matrices. Hum Gene Ther 2002;13(7):791-802. [PubMed: 11975846] 
151. Scharstuhl A, Diepens R, Lensen J, et al. Adenoviral overexpression of Smad-7 and Smad-6 differentially regulates TGF-beta-mediated chondrocyte proliferation and proteoglycan synthesis. Osteoarthritis Cartilage 2003;11(11):773-782. [PubMed: 14609530]

152. Scharstuhl A, Vitters EL, van der Kraan PM, et al. Reduction of osteophyte formation and synovial thickening by adenoviral overexpression of transforming growth factor beta/bone morphogenetic protein inhibitors during experimental osteoarthritis. Arthritis Rheum 2003;48(12):3442-3451. [PubMed: 14673995]

153. Schmidt MB, Chen EH, Lynch SE. A review of the effects of insulin-like growth factor and platelet derived growth factor on in vivo cartilage healing and repair. Osteoarthritis Cartilage 2006;14(5): 403-412. [PubMed: 16413799]

154. Sekiya I, Larson BL, Vuoristo JT, et al. Comparison of effect of BMP-2, -4, and -6 on in vitro cartilage formation of human adult stem cells from bone marrow stroma. Cell Tissue Res 2005;320 (2):269-276. [PubMed: 15778851]

155. Sellers RS, Zhang R, Glasson SS, et al. Repair of articular cartilage defects one year after treatment with recombinant human bone morphogenetic protein-2 (rhBMP-2). J Bone Joint Surg Am 2000;82 (2):151-160. [PubMed: 10682724]

156. Shortkroff S, Yates KE. Alteration of matrix glycosaminoglycans diminishes articular chondrocytes' response to a canonical Wnt signal. Osteoarthritis Cartilage 2007;15(2):147-154. [PubMed: 16908205]

157. Shuler FD, Georgescu HI, Niyibizi C, et al. Increased matrix synthesis following adenoviral transfer of a transforming growth factor beta1 gene into articular chondrocytes. J Orthop Res 2000;18(4): 585-592. [PubMed: 11052495]

158. Smith N, Dong Y, Lian JB, et al. Overlapping expression of Runx1(Cbfa2) and Runx2(Cbfa1) transcription factors supports cooperative induction of skeletal development. J Cell Physiol 2005;203(1):133-143. [PubMed: 15389629]

159. Smith P, Shuler FD, Georgescu HI, et al. Genetic enhancement of matrix synthesis by articular chondrocytes: comparison of different growth factor genes in the presence and absence of interleukin-1. Arthritis Rheum 2000;43(5):1156-1164. [PubMed: 10817570]

160. Song L, Chau L, Sakamoto Y, et al. Electric field-induced molecular vibration for noninvasive, highefficiency DNA transfection. Mol Ther 2004;9(4):607-616. [PubMed: 15093191]

161. Steadman JR, Rodkey WG, Rodrigo JJ. Microfracture: surgical technique and rehabilitation to treat chondral defects. Clin Orthop Relat Res 2001;(391 Suppl):S362-369. [PubMed: 11603719]

162. Steadman JR, Rodkey WG, Briggs KK. Microfracture to treat full-thickness chondral defects: surgical technique, rehabilitation, and outcomes. J Knee Surg 2002;15(3):170-176. [PubMed: 12152979]

163. Steinert A, Weber M, Dimmler A, et al. Chondrogenic differentiation of mesenchymal progenitor cells encapsulated in ultrahigh-viscosity alginate. J Orthop Res 2003;21(6):1090-1097. [PubMed: 14554223]

164. Steinert, A.; Palmer, G.; Ghivizzani, SC., et al. Gene Therapy in the Treatment of Cartilage Injury. In: Mirzajan, R., editor. Cartilage Injury in the Athlete. New York: Thieme Medical Publishers; 2006. p. 297-308.

165. Tavella S, Biticchi R, Schito A, et al. Targeted expression of SHH affects chondrocyte differentiation, growth plate organization, and Sox9 expression. J Bone Miner Res 2004;19(10): 1678-1688. [PubMed: 15355563]

166. Tew S, Redman S, Kwan A, et al. Differences in repair responses between immature and mature cartilage. Clin Orthop Relat Res 2001;391 Suppl:S142-152. [PubMed: 11603699]

167. Tew SR, Li Y, Pothacharoen P, et al. Retroviral transduction with SOX9 enhances re-expression of the chondrocyte phenotype in passaged osteoarthritic human articular chondrocytes. Osteoarthritis Cartilage 2005;13(1):80-89. [PubMed: 15639641]

168. Thomas CE, Ehrhardt A, Kay MA. Progress and problems with the use of viral vectors for gene therapy. Nat Rev Genet 2003;4(5):346-358. [PubMed: 12728277]

169. Tian H, Stogiannidis I. Up-regulation of cartilage oligomeric matrix protein gene expression by insulin-like growth factor-I revealed by real-time reverse transcription-polymerase chain reaction. Acta Biochim Biophys Sin (Shanghai) 2006;38(10):677-682. [PubMed: 17033713] 
170. Tomita T, Hashimoto $\mathrm{H}$, Tomita N, et al. In vivo direct gene transfer into articular cartilage by intraarticular injection mediated by HVJ (Sendai virus) and liposomes. Arthritis Rheum 1997;40 (5):901-906. [PubMed: 9153552]

171. Trippel SB, Ghivizzani SC, Nixon AJ. Gene-based approaches for the repair of articular cartilage. Gene Ther 2004;11(4):351-359. [PubMed: 14724680]

172. Tsuchiya H, Kitoh H, Sugiura F, et al. Chondrogenesis enhanced by overexpression of sox9 gene in mouse bone marrow-derived mesenchymal stem cells. Biochem Biophys Res Commun 2003;301 (2):338-343. [PubMed: 12565865]

173. Tsumaki N, Tanaka K, Arikawa-Hirasawa E, et al. Role of CDMP-1 in skeletal morphogenesis: promotion of mesenchymal cell recruitment and chondrocyte differentiation. J Cell Biol 1999;144 (1):161-173. [PubMed: 9885252]

174. Tuan R. Boning up on telomerase. Nat Biotechnol 2002;20(6):560-561. [PubMed: 12042856]

175. Tuan RS, Boland G, Tuli R. Adult mesenchymal stem cells and cell-based tissue engineering. Arthritis Res Ther 2003;5(1):32-45. [PubMed: 12716446]

176. Tuan RS. Stemming cartilage degeneration: adult mesenchymal stem cells as a cell source for articular cartilage tissue engineering. Arthritis Rheum 2006;54(10):3075-3078. [PubMed: 17009225]

177. Tuli R, Li WJ, Tuan RS. Current state of cartilage tissue engineering. Arthritis Res Ther 2003;5(5): 235-238. [PubMed: 12932283]

178. Tuli R, Tuli S, Nandi S, et al. Transforming growth factor-beta-mediated chondrogenesis of human mesenchymal progenitor cells involves $\mathrm{N}$-cadherin and mitogen-activated protein kinase and Wnt signaling cross-talk. J Biol Chem 2003;278(42):41227-41236. [PubMed: 12893825]

179. Tyler JA. Insulin-like growth factor 1 can decrease degradation and promote synthesis of proteoglycan in cartilage exposed to cytokines. Biochem J 1989;260(2):543-548. [PubMed: 2788408]

180. Valhmu WB, Palmer GD, Dobson J, et al. Regulatory activities of the 5'- and 3'-untranslated regions and promoter of the human aggrecan gene. J Biol Chem 1998;273(11):6196-6202. [PubMed: 9497342]

181. van Osch GJ, van den Berg WB, Hunziker EB, et al. Differential effects of IGF-1 and TGF beta-2 on the assembly of proteoglycans in pericellular and territorial matrix by cultured bovine articular chondrocytes. Osteoarthritis Cartilage 1998;6(3):187-195. [PubMed: 9682785]

182. Venkatesan N, Barre L, Benani A, et al. Stimulation of proteoglycan synthesis by glucuronosyltransferase-I gene delivery: a strategy to promote cartilage repair. Proc Natl Acad Sci U S A 2004;101(52):18087-18092. [PubMed: 15601778]

183. Vivien D, Galera P, Lebrun E, et al. Differential effects of transforming growth factor-beta and epidermal growth factor on the cell cycle of cultured rabbit articular chondrocytes. J Cell Physiol 1990;143(3):534-545. [PubMed: 2358472]

184. Vortkamp A, Lee K, Lanske B, et al. Regulation of rate of cartilage differentiation by Indian hedgehog and PTH-related protein. Science 1996;273(5275):613-622. [PubMed: 8662546]

185. Vortkamp A. Interaction of growth factors regulating chondrocyte differentiation in the developing embryo. Osteoarthritis Cartilage 2001:AS109-117.

186. Wakitani S, Imoto K, Kimura T, et al. Hepatocyte growth factor facilitates cartilage repair. Full thickness articular cartilage defect studied in rabbit knees. Acta Orthop Scand 1997;68(5):474-480. [PubMed: 9385250]

187. Wakitani S, Mitsuoka T, Nakamura N, et al. Autologous bone marrow stromal cell transplantation for repair of full-thickness articular cartilage defects in human patellae: two case reports. Cell Transplant 2004;13(5):595-600. [PubMed: 15565871]

188. Weisser J, Rahfoth B, Timmermann A, et al. Role of growth factors in rabbit articular cartilage repair by chondrocytes in agarose. Osteoarthritis Cartilage 2001:AS48-54.

189. Whalen JD, Lechman EL, Carlos CA, et al. Adenoviral transfer of the viral IL-10 gene periarticularly to mouse paws suppresses development of collagen-induced arthritis in both injected and uninjected paws. J Immunol 1999;162(6):3625-3632. [PubMed: 10092823]

190. Worster AA, Brower-Toland BD, Fortier LA, et al. Chondrocytic differentiation of mesenchymal stem cells sequentially exposed to transforming growth factor-beta1 in monolayer and insulin-like 
growth factor-I in a three-dimensional matrix. J Orthop Res 2001;19(4):738-749. [PubMed: 11518286]

191. Xie WF, Zhang X, Sakano S, et al. Trans-activation of the mouse cartilage-derived retinoic acidsensitive protein gene by Sox9. J Bone Miner Res 1999;14(5):757-763. [PubMed: 10320524]

192. Yao Q, Glorioso JC, Evans CH, et al. Adenoviral mediated delivery of FAS ligand to arthritic joints causes extensive apoptosis in the synovial lining. J Gene Med 2000;2(3):210-219. [PubMed: 10894267]

193. Yao Q, Wang S, Gambotto A, et al. Intra-articular adenoviral-mediated gene transfer of trail induces apoptosis of arthritic rabbit synovium. Gene Ther 2003;10(12):1055-1060. [PubMed: 12776164]

194. Yokoo N, Saito T, Uesugi M, et al. Repair of articular cartilage defect by autologous transplantation of basic fibroblast growth factor gene-transduced chondrocytes with adeno-associated virus vector. Arthritis Rheum 2005;52(1):164-170. [PubMed: 15641065]

195. Yoo JU, Barthel TS, Nishimura K, et al. The chondrogenic potential of human bone-marrow-derived mesenchymal progenitor cells. J Bone Joint Surg Am 1998;80(12):1745-1757. [PubMed: 9875932]

196. Yoo JU, Mandell I, Angele P, et al. Chondrogenitor cells and gene therapy. Clin Orthop 2000;(379 Suppl):S164-170. [PubMed: 11039766]

197. Zhou G, Lefebvre V, Zhang Z, et al. Three high mobility group-like sequences within a 48-base pair enhancer of the Col2a1 gene are required for cartilage-specific expression in vivo. J Biol Chem 1998;273(24):14989-14997. [PubMed: 9614106]

198. Zuk PA, Zhu M, Mizuno H, et al. Multilineage cells from human adipose tissue: implications for cell-based therapies. Tissue Eng 2001;7(2):211-228. [PubMed: 11304456] 


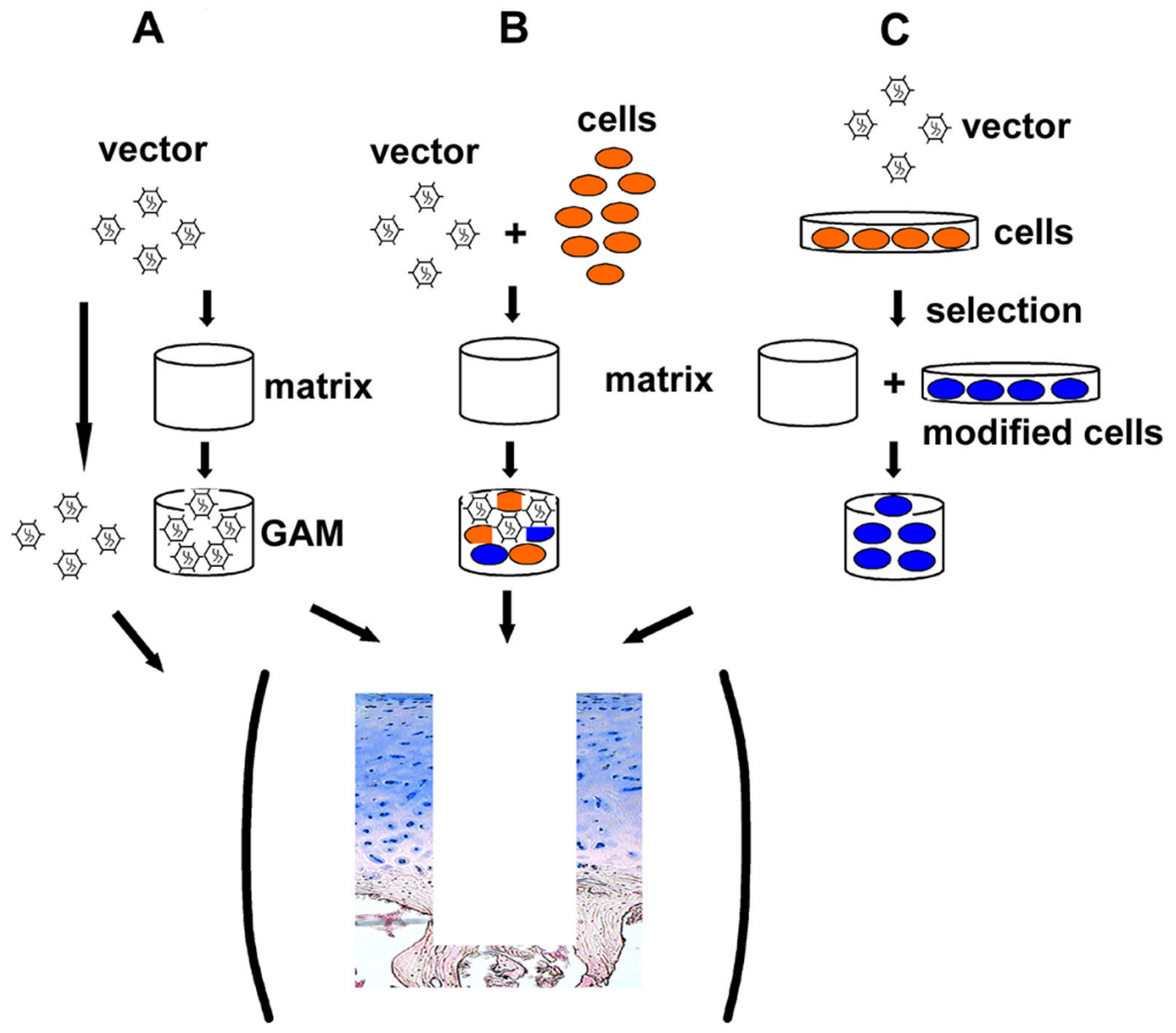

Figure 1.

Gene transfer approaches for the treatment of cartilage defects. (A) For in vivo gene transfer, free vector is either injected directly into the joint space, or incorporated into a biologically compatible matrix before implantation into a cartilage defect (gene activated matrix (GAM) implantation). Resident cells that encounter the vector acquire the desired gene, and genetically modified cells secrete the transgene products that influence the regeneration of articular cartilage. (B) Abbreviated ex vivo genetically enhanced tissue engineering to treat cartilage defects. A vector is incorporated into the matrix together with cells that are harvested at the same operative setting, such as stromal cells from bone marrow aspirates. (C) Ex vivo genenetically enhanced tissue engineering for cartilage repair involves the harvest and expansion of target cells in vitro, which are subsequently infected with the desired vector. The transduced cells then may be selected, and seeded into a biological matrix before the construct is transplanted into a cartilage defect. Depending on the approach chosen, ubiquitous or local transgene expression (TGE) is induced by the genetically modified cells, and the gene products could beneficially influence cartilage repair by either transplanted cells as well as those that may migrate into the defect site. 
Table 1

Classes of gene products that aid cartilage repair

\begin{tabular}{|c|c|c|}
\hline Therapeutic mechanism & Gene product & Examples/References \\
\hline \multicolumn{3}{|c|}{ Stimulation of chondrogenic differentiation } \\
\hline \multirow[t]{4}{*}{ Anabolic growth factors } & TGF- $\beta 1,2,3$ & {$[14,95,135,138,157,190]$} \\
\hline & BMP-2, $-4,-7$ & {$[1,27,36,38,57,70,75,116,139,154,155,163]$} \\
\hline & CDMP-1, -2, -3 (GDF-5, -6, -7) & {$[68,90,133,173]$} \\
\hline & Wnts & {$[51,81,156,178]$} \\
\hline Signal transduction molecules & Smad-4, -5 & {$[76,83,151]$} \\
\hline Transcription factors & SOX9, $-5,-6$ & {$[33,97-99,166,167,172]$} \\
\hline & Brachyury & [77] \\
\hline
\end{tabular}

Stimulation of cartilage matrix synthesis and/or cell proliferation
Anabolic growth factors
TGF- $\beta 1,2,3$
$[14,95,135,138,157,190]$
BMP-2, $-4,-7$
$[1,27,36,38,57,70,75,116,139,154,155,163]$
CDMP-1, -2, -3 (GDF-5, -6, -7)
$[68,90,133,173]$
IGF-1
[53,55,73,107,110,119,131,132,153,159,169,179,181,190]
PDGF, EGF, HGF
$[7,153,169,183,186,188]$
ECM component
Type II collagen minigene
[37]
COMP
[118]
Enzymes for GAG synthesis
GlcAT-1
$[13,182]$

Inhibition of osteogenesis/hypertrophy

Growth factors

$\begin{array}{cll}\text { Inhibiting TGF- } \beta \text { /BMP action } & \text { Noggin, Chordin } & {[72,142]} \\ \text { Inhibiting terminal differentiation } & \text { PTHrP } & {[45,124]} \\ & \text { IHH, SHH, DHH } & {[67,85,165,185,184]} \\ \text { Signal transduction molecules } & \text { Smad 6, 7 } & {[83,151]} \\ & \text { mLAP-1 } & {[152]}\end{array}$

\section{Anti-inflammatory}

IL-1 blockage (cytokine antagonist)

IL-1Ra, sIL-1R, ICE inhibitor

$[6,8,10,11,52,62-64,73,113,129,132,137,143,149]$

TNF- $\alpha$ inhibition (cytokine antagonist)

sTNFR, anti-TNF-antibodies, TACE Inhibitor

$[29,30,35,60,103,148]$

MMP Inhibition (proteinase inhibitor)

TIMP-1, -2, MMP inhibitors

$[88,103,148]$

Cytokines

IL-4, -10, -11, -13

$[2,3,4,5,87,94,101,103-105,111,126,129,189]$

Enzymes for glucosamine derivates (IL-1 inhibition)

GFAT

$[65,66]$

Senescence inhibition
Inhibition of telomere erosion
hTERT
[115,174]
Free radical antagonist
NO-(iNOS) antagonists, SOD
$[16,43,101,112,115]$

Apoptosis inhibition

Injury. Author manuscript; available in PMC 2009 July 22. 


\begin{tabular}{|lll|}
\hline Therapeutic mechanism & Gene product & Examples/References \\
Caspase inhibition & Bcl-2, Bcl-XL & {$[39-41]$} \\
Fas-L blockage & Anti-FasL & {$[40,78,192]$} \\
NO-induced apoptosis & Akt, PI-3-kinase & {$[102,125]$} \\
TNF- $\alpha$, TRAIL Inhibition & NFkB & {$[60,79,193]$} \\
\hline
\end{tabular}


Table 2

Nonviral and viral vectors for orthopaedic gene therapy applications

\begin{tabular}{|c|c|c|c|}
\hline Vector & Description & Advantages & Disadvantages \\
\hline Naked DNA & Naked or uncomplexed DNA & \multirow{3}{*}{$\begin{array}{l}\text { Easy to manufacture } \\
\text { Non-infectious (safety) }\end{array}$} & \multirow{3}{*}{$\begin{array}{l}\text { Low transfection efficiency } \\
\text { Transient transgene expression (less than } 1 \text { week } \\
\text { Inflammatory }\end{array}$} \\
\hline Liposomes & $\begin{array}{l}\text { Plasmid DNA delivered in a } \\
\text { phospholipid vesicle that } \\
\text { merges with host cell }\end{array}$ & & \\
\hline Others & $\begin{array}{l}\text { DNA-injection, } \\
\text { Biolistics (gene gun), } \\
\text { Electroporation, } \\
\text { Ca/P precipitation }\end{array}$ & & \\
\hline Adenovirus & $\begin{array}{l}\text { dsDNA virus } \\
35 \mathrm{~kb} \text { genome } \\
\text { Episomal } \\
\text { Delivers DNA } \\
\text { Divided in } 100 \text { map units (E1- } \\
\text { E4) } \\
7.5 \mathrm{~kb} \text { capacity } \\
\text { Multiple serotypes }\end{array}$ & $\begin{array}{l}\text { Infects dividing and non-dividing } \\
\text { cells } \\
\text { High transduction efficieny } \\
\text { High levels of transgene expression } \\
\text { Straightforward production } \\
\text { High titer } \\
\text { Approved for use in clinical trials }\end{array}$ & $\begin{array}{l}\text { Transient transgene expression } \\
\text { Immunogenicity of transduced cells } \\
\text { Cytotoxic at high doses }\end{array}$ \\
\hline Adeno-Associated Virus (AAV) & $\begin{array}{l}\text { ssDNA virus } \\
8 \text { serotypes, with AAV- } 2 \text { with } \\
\text { highest chondrocyte and MSC } \\
\text { tropism } \\
\text { Wild-type AAV integrates } \\
\text { Recombinant AAV appears to } \\
\text { be non-integratig } \\
4 \text { kb capacity }\end{array}$ & $\begin{array}{l}\text { Infects dividing and non-dividing } \\
\text { cells } \\
\text { No viral protein expression in } \\
\text { infected cells } \\
\text { Not known to cause disease in } \\
\text { humans } \\
\text { Biologically relevant transgene } \\
\text { expression after direct i.a. delivery }\end{array}$ & $\begin{array}{l}\text { Transient transgene expression } \\
\text { Moderate transduction efficiency } \\
\text { Moderate levels of transgene expression } \\
\text { Difficult to manufacture } \\
\text { Small capacity }\end{array}$ \\
\hline Herpes Simplex Virus (HSV) & $\begin{array}{l}\text { dsDNA virus } \\
\text { Delivers episomal DNA } \\
40 \text { kb capacity }\end{array}$ & $\begin{array}{l}\text { Infects dividing and non-dividing } \\
\text { cells } \\
\text { Very high transduction efficiency } \\
\text { Very high levels of transgene } \\
\text { expression } \\
\text { Large capacity }\end{array}$ & $\begin{array}{l}\text { Transient transgene expression } \\
\text { Viral protein expression in infected cells } \\
\text { Cytotoxic } \\
\text { Immunogenic }\end{array}$ \\
\hline Foamyvirus (FV) & $\begin{array}{l}\text { RNA virus } \\
\text { Integrates in genome } \\
10-13 \mathrm{~kb} \text { capacity }\end{array}$ & $\begin{array}{l}\text { Large capacity } \\
\text { Persistent transgene expression } \\
\text { No viral protein expression in } \\
\text { infected cells } \\
\text { Favorable integration pattern } \\
\text { Foamy/adeno hybrid vectors } \\
\text { possible }\end{array}$ & $\begin{array}{l}\text { Possible insertional mutagenesis } \\
\text { Low titer with FV }\end{array}$ \\
\hline $\begin{array}{l}\text { Moloney Murine Leukemia Virus } \\
\text { (MoMLV) }\end{array}$ & $\begin{array}{l}\text { RNA virus } \\
\text { Integrating } \\
4-6 \text { kb capacity }\end{array}$ & $\begin{array}{l}\text { Persistent transgene expression } \\
\text { No viral protein expression in } \\
\text { infected cells }\end{array}$ & $\begin{array}{l}\text { Only infects dividing cells } \\
\text { Possible insertional mutagenesis }\end{array}$ \\
\hline Lentivirus & $\begin{array}{l}\text { RNA virus } \\
\text { Integrates in genome } \\
4-6 \text { kb capacity }\end{array}$ & $\begin{array}{l}\text { Infects dividing and non-dividing } \\
\text { cells } \\
\text { High transduction efficiency and } \\
\text { persistent transgene expression } \\
\text { No viral protein expression in } \\
\text { infected cells }\end{array}$ & Possible insertional mutagenesis \\
\hline
\end{tabular}




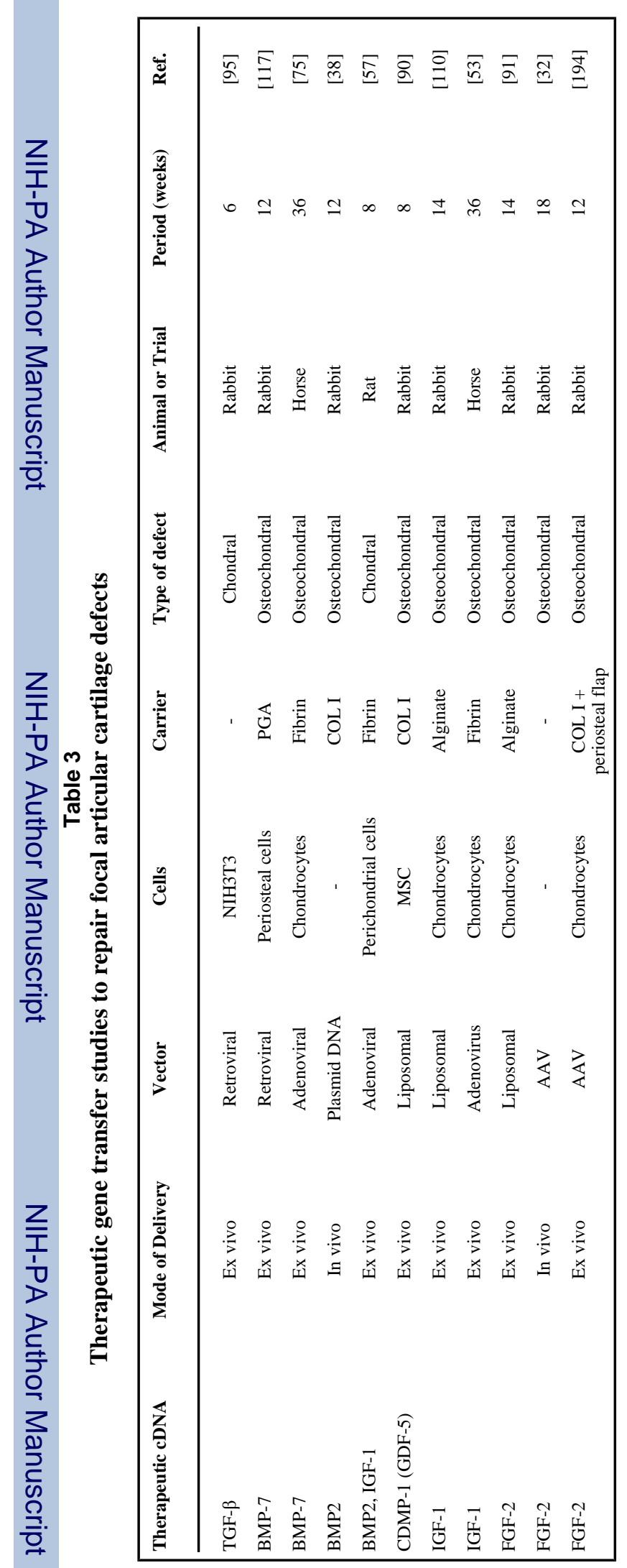

Injury. Author manuscript; available in PMC 2009 July 22. 